\title{
CHARACTERS OF TWO UNDESCRIBED LAND SHELLS FROM THE REPUBLIC OF COLOMBIA AND A NEW GENUS OF HELICOIDS.
}

\author{
By G. K. Gude, F.Z.S. \\ Read 12th Jamuary, 1912.
}

TнE shells forming the subject of the present communication were collected in the United States of Colombia at an altitude of 5,600 feet near Alejandria, a place 50 miles from Medellin, by Mr. T. P. Sharman, a mining engineer, who is also a good naturalist and sportsman. They were forwarded by him to Major A. J. Peile, who sent them to me for identification, and as they appeared to be new to science he obligingly placed them at my disposal for description.

The first species belongs to a small group of Helicidæ, of which hitherto only three species were known, two of which Professor Pilsbry assigned to Isomeria, namely, Pleurodonta vexans, Dohrn, and P. anigma, Dohrn, ${ }^{1}$ while the third species, L. assimilans, Smith, ${ }^{2}$ was referred by Mr. E. A. Smith to Labyrinthus. The former two species were regarded by Pilsbry "as an independent line of evolution from typical Isomeria, rather than as an intermediate or ancestral form between Isomeria and Labyrinthus ". Previously, however, he had regarded the group intermediate between these two sections. ${ }^{3}$ Since this group does not, in $\mathrm{my}$ opinion, assimilate with either section named, I adopt his earlier view and therefore dissociate it from Isomeria, and propose to create for its reception the genus Ambages," taking $P$. vexans as the type. It differs from Isomeria in having the teeth more strongly developed, and from Labyrinthus in the sub-globose depressed form.

\section{Ambages Sharmani, n.gen. et n.sp.}

Shell umbilicate, depressed orbicular, closely striated, the striæ broken up into rather coarse granules; light brown. spire sub-convex, suture impressed, apex obtuse. Whorls $4 \frac{3}{4}$, increasing regularly, slightly convex above, tumid below, penultimate whorl angulated, last whorl rounded at the periphery, suddenly and shortly deflexed at the mouth, slightly constricted behind the peristome, and bi-scrobiculate behind the basal margin. Aperture oblique, rhomboid; peristome white, expanded and reflexed, continuous; outer margin semicircular, basal margin slightly incurved, columellar margin projecting over the umbilicus, parietal margin nearly straight. Aperture provided with four folds, namely, two equal, short, transverse, entering, convergent folds-one on the basal and one on the outer margin; a third fold, close to the latter, but less elevated,

${ }^{1}$ Man. Conch., vol. ix, p. 94, 1894.

2 Journ. Malac., vol. vi, p. 27, pl. iv, figs. 6-8, 1897.

3 Man. Conch., vol. v, p. 157, 1889.

${ }^{4}$ Ambages, 'obscurity.' 
occurs on the outer margin, nearly parallel with the peristome, its upper termination bent slightly forward; on the parietal wall is a low bifurcated entering fold, its lower arm terminating close to the peristome, descending abruptly, its upper arm shorter, descending gradually. Diam. maj. 21, min. $18.5 \mathrm{~mm}$; alt. $10 \mathrm{~mm}$.

Hab.-Alejandria, Republic of Colombia.

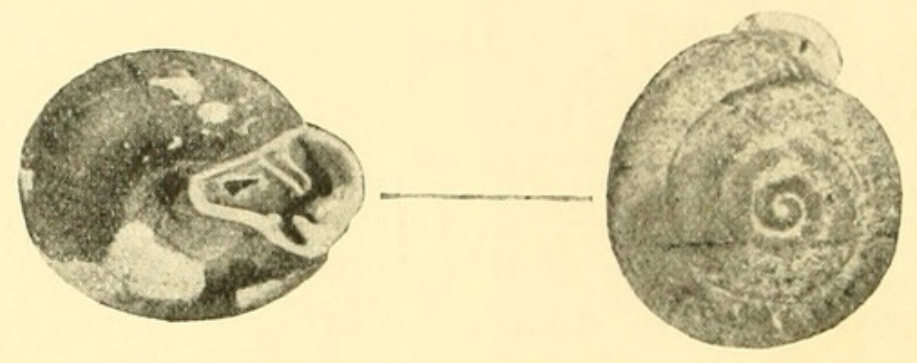

Type in the British Museum, presented by Major A. J. Peile, R.A.

The new species is nearest to $P$. vexans, but is smaller and more distinctly and coarsely granulated, almost beaded. It differs further in having a white peristome, in having the upper fold parallel with, instead of transverse to, the peristome, in the fold on the basal margin being oblique, in the junction of the basal and outer margins being more acute, in the straight parietal margin, and finally in the bifurcate entering parietal fold. The aperture in shape resembles more that of Labyrinthus triplicata, Mart.

\section{Neocyclotus Peilei, n.sp.}

Shell somewhat narrowly umbilicated, depressed turbinate, more or less striated transversely, the striæ being intersected by other striæ descending obliquely forward, thus forming coarse granules

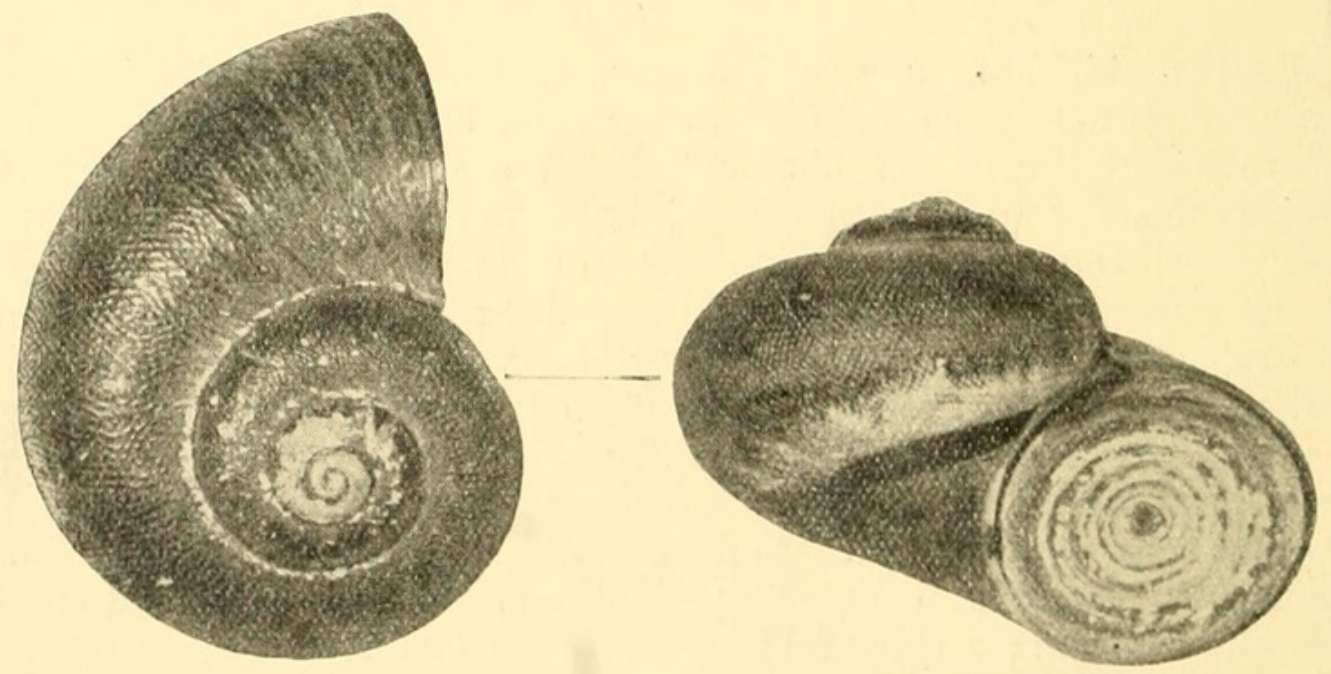

arranged in quincunx, except in a few scattered places where a portion of either set of striæ is continuous, in some instances even forming zigzag lines, while near the peristome the oblique striæ tend to disappear and the granules become obsolete. Whorls 5, 
convex, increasing rather slowly at first, the last increasing rapidly, and dilated towards the mouth; the earlier whorls pale brown, becoming gradually darker, the last dark brown with blackish streaks at the lines of growth, descending slowly in front. Aperture circular, scarcely oblique; peristome simple, acute, slightly sinuate at the junction of the upper and columellar margins; operculum slightly concave. Diam. maj. $39 \cdot 5$, min. $30 \mathrm{~mm}$. ; alt. $30 \mathrm{~mm}$.

Type in the British Museum, presented by Major Peile.

Its nearest ally appears to be Neocyclotus Belli, Beddome, ${ }^{1}$ but that species is considerably larger, and lacks the coarse granules so conspicuous a feature in the present species.

1 These Proceedings, vol. viii, p. 20, 1908. 


\section{$2 \mathrm{BHL}$ Biodiversity Heritage Library}

Gude, Gerard Kalshoven. 1912. "CHARACTERS OF TWO UNDESCRIBED LAND SHELLS FROM THE REPUBLIC OF COLOMBIA AND A NEW GENUS OF HELICOIDS." Proceedings of the Malacological Society of London 10, 21-23. https://doi.org/10.1093/oxfordjournals.mollus.a063457.

View This Item Online: $\underline{\text { https://www.biodiversitylibrary.org/item/52423 }}$

DOI: https://doi.org/10.1093/oxfordjournals.mollus.a063457

Permalink: https://www.biodiversitylibrary.org/partpdf/203073

\section{Holding Institution}

Smithsonian Libraries

\section{Sponsored by}

Smithsonian

\section{Copyright \& Reuse}

Copyright Status: Public domain. The BHL considers that this work is no longer under copyright protection.

This document was created from content at the Biodiversity Heritage Library, the world's largest open access digital library for biodiversity literature and archives. Visit BHL at https://www.biodiversitylibrary.org. 